J O H H. M C D O W E L L

\title{
Folklore as Commemorative Discourse
}

This article inspects a ballad performance to assess the relationship beween poetic and prose narrative, between the language of the song and the language that surrounds it in the singing event. Contrasting discourse types, the informative and the commemorative, are identified and discussed. Commemorative utterance exhibits regularized acoustic textures in presenting what are taken for immanent truths. Such discourse possesses remarkable efficacy, due in part to the impact of measured and allusive speech on the central nervous system, and to the exploitation of these effects in appropriately orchestrated social settings.

\begin{abstract}
A rhythm is a promise which the poet makes to the reader-and in proportion as the reader comes to rely on this promise, he falls into a state of general surrender which makes him more likely to accept without resistance the rest of the poet's material. -Kenneth Burke, 1931

The purpose of rhythm is to prolong the moment of contemplation, the moment when we are both asleep and awake, which is the moment of creation, by hushing us with an alluring monotony, while it holds us waking by variety, to keep us in that state of perhaps real trance, in which the mind, liberated from the pressure of the will, is unfolded in symbols.
\end{abstract}

—William Butler Yeats, 1903

The fundamental conditions of a rhythmic experience are to be found in the laws of periodicity of functioning in the nervous system. An objective stimulation (rhythm) must be coordinated with some internal mechanism in order for the impression of rhythm to arise.

-R. McDougall, 1902

IN THESE PAGES I INVESTIGATE THE IMPACT OF ORAL POETRY by exploring the relationship between prose and poetic narrative dedicated to telling a story in the context of a complex performance event. Folklorists rarely encounter poetic discourse in isolation from a conversational discourse environment. Performances of märchen, ballads, and other more formalized expressive genres are typically anchored in a conversational flow attending to the ritual constraints of talk (Goffman 1981), that is, to the maintenance of social face, and to the exegesis of plot elements not fully illuminated in the poetry (see Basgoz 1986).

Work informed by a previous paradigm ("the text is the thing") tended to excise or segregate this ambient discourse, thereby dissolving the natural interplay of talk and song, of prose and poetic narrative. Much is lost in the weeding process that leaves standing only the text of the "artistic" perfor- 
mance. I hope to demonstrate that important theoretical insights can be derived from the examination of the peculiar bond linking these contrastive discourse styles. I will designate them as informative and commemorative, and argue that they contrast systematically on stylistic, semantic, and functional grounds. The verbal genres of folklore gravitate toward the commemorative as I will define it, and I wish to tackle in this article issues raised by the manifest potency of speech in the commemorative vein. It will be necessary to account for the characteristic form, content, mission, and modus operandi of commemorative discourse as it occurs in the world's societies. But these issues are best brought into focus by addressing first the complementarity of these two kinds of verbal instruments, the informative and the commemorative, in a specific context of verbal performance.

\section{Sidonio's Ballad}

I propose to ground this discussion in one memorable singing of the ballad known as "El Corrido de Sidonio." There is a remarkable town in the Mexican state of Guerrero known as Cruz Grande, "Large Cross," so named (the story goes) for a large wooden cross that washed ashore nearby and was subsequently installed in this town. Cruz Grande was first settled by cimarrones, escaped slaves who eluded the reach of Spanish wrath. Today one searches in vain for any sign of that cross along the dusty streets of Cruz Grande, with its irregular rows of wattle-and-daub, adobe, and, occasionally, cinder-block houses. I have been to Cruz Grande twice. The first time was in 1972 when I was a graduate student in search of the living ballad; on that occasion I immediately sought refuge with the presidente municipal, the mayor of the town, after noticing, as I turned off the highway, that men walked about carrying pistols and rifles. As it happened, this affable gentleman, señor Austreberto Gallardo, provided me not only with refuge but also with an evening of corridos [ballads], as various uncles and friends were called to his home to make music. ${ }^{1}$

I returned to Cruz Grande in January of 1989 to find that an army battalion had been established on the other side of the national highway; the men now walk about with pistols discreetly tucked underneath their shirts and jackets. This time around my wife and I made the acquaintance of Raúl Mayo, an earnest young man who escorted us about and arranged for a song session with his uncle, Ernesto Gallardo, and a friend, Alejandro Mejías. This visit, too, produced a harvest of ballads, and I wish to situate this inquiry into commemorative discourse within one ballad performance and the verbal counterpoint that surrounded it. In my experience, ballad performances often involve a conversational prologue and epilogue allowing performers and audience members to indulge in commentary about the songs, and it is an instance of this verbal counterpoint that will occupy us in the pages to follow.

"The Corrido of Sidonio" was the most stirring of several ballads performed that afternoon by Ernesto and Alejandro, who seemed to find an evoc- 
ative groove and sustain it throughout the performance. Also of interest were the asides tossed by Ernesto to Raúl, our escort, in between stanzas of the song. The main protagonist in this song is a first cousin of Raúl's father, and Ernesto's quips are meant to recognize this fact. There are two primary discourses accomplishing the presentation of Sidonio's story: the discourse of song, which can be thought of as the musical apotheosis of speech, and the explanatory commentary following the song, executed in a conversational modality. The banter that occurred between Ernesto and Raúl during the performance is a third discourse component, one that straddles the divide between speech and song in a number of interesting ways. Although they differ from one another on stylistic grounds, these discourses are bound together as instruments in conveyance of a narrative plot.

Here are the relevant transcriptions:

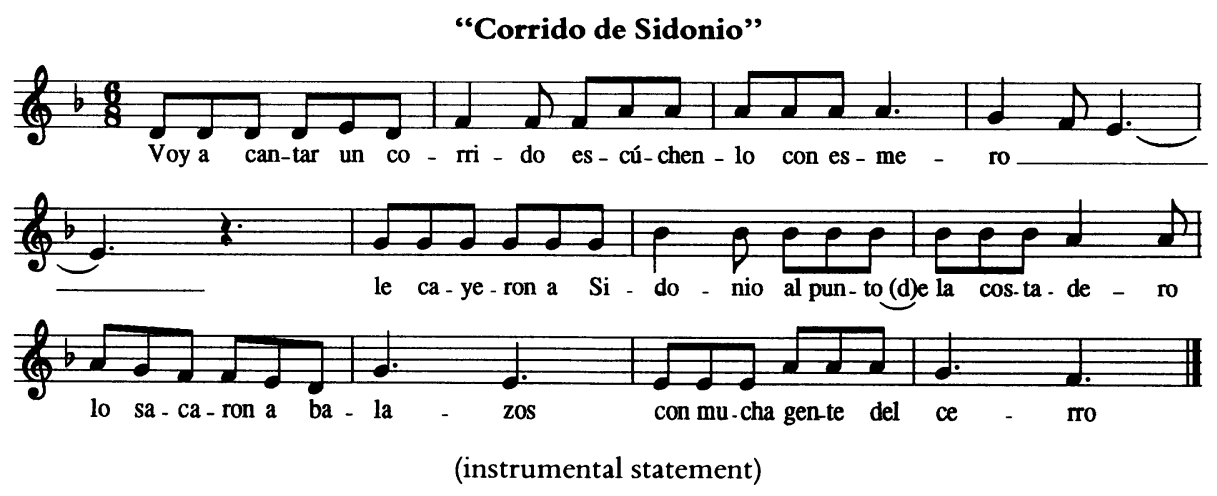

(1)

Voy a cantar un corrido escúchenlo con esmero, le cayeron a Sidonio al punto de la costadero, lo sacaron a balazos con mucha gente del cerro.

(2)

Sidonio no quería creer que Santa Rosa pesaba, pidiéndoles de favor la pasara de la barra, porque esa gente de Lorenzo la verdad estaba muy brava.

(3)

Teófilo la Chichacola era un hombre, no se rajaba, en la barra de Chautengo tenía la sombra pesada, la escopetita del doce seguido se la tronaba.
I will sing a corrido listen to this with care, they fell upon Sidonio by the edge of the coastal highway, they drew him out with bullets with several men from the highlands.

Sidonio didn't want to believe that Santa Rosa was for real, asking them as a favor that they pass her over from her gang, because those people of Lorenzo's in truth they were very angry.

Teófilo the Locust he was a man, he didn't back down, among the gang of Chautengo he cast a heavy shadow, that 12-gauge shotgun he fired it off right away. 
(instrumental statement)

(4)

Ese Pipino Lorenzo

se cubrió por los retoños, porque le escucha la habla

a su compadre Sidonio,

quería que saliera afuera

para meterlo unos plomos.

[Spoken]

Ernesto: Lo quería mucho.

[He was really fond of him.]

Raúl: Bastante.

[Plenty.]

(5)

Pirro García les gritaba:

“Todavía esta no es de creer,

éntrenle aquí está su padre

aquí traigo el cero-seis,

no lo compré pa mi padre

voy a vengar a José."

[Spoken]

Ernesto: Estaba sencillo.

[It was easy.]

(6)

Ese Filimón Lorenzo

le gritaba de valor,

con una pistola super

le gritaba, Filimón:

"Yo soy de tus enemigos

no tomes otra cuestión."

(7)

Prisca Soto se murió

según ya eso era su siño,

[Spoken]

Ernesto: Esa era su mujer, de ello

[That was his wife, his]

no le tiraron a ella

le tiraron al marido,

según no quería morir

pero ya eso era su siño.

[Spoken]

Ernesto: Su siño como dice, "Ahí te va pues!"

[His sign, as they say: "So there you go!”]

(8)

Ya me voy a despedir

escúchenlo con esmero,

\section{That Pipino Lorenzo}

he took cover in the brush, because he hears the voice of his compadre Sidonio, he wanted him to come outside so he could fill him with lead.

Pirro García shouted to them:

“This can't be for real, come on in, here is your father here I've got the aught-six, I didn't buy it for my father I'm going to take revenge for José."

\author{
That Filimón Lorenzo \\ he shouted with valor, \\ with his super pistol \\ he shouted, Filimón: \\ "I am one of your enemies \\ don't take it any other way."
}

\section{Prisca Soto died}

since his time was already at hand,

they didn't shoot at the woman they shot her husband instead, though he didn't want to die but his time was already at hand. 
le cayeron a Sidonio

al punto de la costadero,

lo sacaron de balazos

con mucha gente del cerro. they fell upon Sidonio

by the edge of the coastal highway,

they drew him out with bullets

with several men from the highlands.

(Applause)

\section{[Spoken]}

1. Raúl: Bravo.

2. Allí onde dice, "la chichacola," es un animal,

sí lo conoce, ¿o no lo conoce?

[There where it says, "la chichacola," it's an animal, you know it, or don't you know it?]

3. John: No.

4. Raúl: Que está en las palmas, ¿no?

[That you find in the palm trees, right?]

5. Ernesto: Sí, en las palmas.

[Yes, in the palm trees.]

6. Raúl: Ahá, pero pica, pa la vaca es mortal la chichacola.

[Aha, but it bites, it is deadly for the cattle.]

7. Ernesto: Sí, no, picándola ya se muere.

[Yes, when it bites them, they die.]

8. Raúl: Por eso allí se dice, si va a traducir, allí onde dice "la chichacola," quiere decir que es una animal peligroso, tipo de hormiga, algo como la hormiga.

[So there it says, if you are going to translate, there where it says, "la chichacola," it means that it is a dangerous animal, like an ant, something like an ant.]

9. Ernesto: Es como la abeja, ¿eh?

[It's like the bee, eh?]

10. John: Sí, y mata.

[Yes, and it kills.]

11. Ernesto: Sí, picando ya . . .

[Yes, when it bites, then ... ]

12. Alejandro: Pero no vuela, nada mas . . .

[But it doesn't fly, it just . . .]

13. Raúl: Anda así en las palmas ...

[It stays like that in the palms ...]

14. John: Ha ...

15. Raúl: . . pero picando una vaca, dentro de poco, pum.

[. . . but biting a cow, very soon, pum.]

16. Ernesto: Sí, no, lo mata de volada, luego.

[Yes, it kills them quickly, right away.]

17. Raúl: A la vaca va a matar, pero para nostros, no. [It will kill a cow, but for us, no.]

18. Ernesto: No, para nosotros no.

Este, a veces como, este, 
cojimos el camino aquí para la laguna,

y bueno, hay que tomar cocos.

Nos fuimos a la palma, a los cocos, y allí hay bastantes.

$\mathrm{Y}$ nos pican y nosotros bajamos los cocos de volado,

es mucho trabajo.

[No, for us, no.

Well, sometimes, well,

we take the path to the laguna,

and fine, you have to try some coconut.

We went for the palms, the coconuts, and there are lots of them there.

And they are biting us and we bring down the coconuts quickly,

it's a lot of work.]

19. Raúl: Ellos saben que no son de ustedes.

[They know they are not yours.]

20. Ernesto: Sí, no nos hace nada.

[Really, it doesn't bother us at all.]

21. John: Ah, ¿ sí?

[Oh, really?]

22. Raúl: Sí, pero es peligroso

[Yes, but it's dangerous.]

23. Ernesto: La chichacola.

This corrido, like so many others with a local circulation, tells a story that is as remarkable for what is absent as it is for what is present. Frank Kermode has written of "the sensory limitations to which narrative is prone: blindness, deafness, an intermittency of memory" (1979:14), but this story seems to revel in the inherent opacity of narrative. We learn that a shoot out has occurred but we gain only an approximate grasp of the particulars. It is as if we witness the events through a mist; only sporadically does a shrouded figure emerge from the fog, and then only to shout out an enigmatic challenge to another barely perceptible figure. Ballads are famous for their leaping and lingering technique (Gummere 1907), and D. K. Wilgus and Eleanor Long have noted that balladry created for local circulation is virtually "freed from the necessity of presenting circumstantial detail" (1985:443). Like the "blues ballads" they discuss, this corrido presents no coherent chronology of events. Instead, its narrator adorns significant moments in a presumed story with dramatic ornaments, often in the form of decisive reported speech acts.

This reticence on the part of the narrator indicates that the story is designed for local consumption; that is, it presupposes an audience already familiar with the narrative matrix. Residents of Cruz Grande and neighboring settlements along the Costa Chica already know about the quarrel between the Gallardo and the Mejías families. They are all too familiar with the feuds that have taken so many lives along the coast, feuds played out locally but fueled by regional, state, and even national political intrigue (see Greenberg 1989). Those who pay attention to local history would remember Sidonio Mayo's attempt to acquire the troublesome woman (unnamed in this corrido) from the Santa Rosa gang 
on behalf of Lorenzo and his people. They would recall the events that followed from this miscalculated attempt at mediation. Names like Teófilo la Chichacola and Filimón Lorenzo resound within the memory of the community; they are emblematic of what Aguirre Beltrán characterizes as the ethos agresivo, the stance of unreconstructed machismo that has plagued this region from time immemorial (1958:131).

In such an environment, the task of the corrido is not to relay fresh news, but rather to commemorate events that are already known, in their specific detail by some, in the broad outline by virtually everybody. The corrido offers an artistic shading of these events, a "literary" interpretation that revolves around episodes of defiant speech at key moments in the unfolding plot. The protagonists emerge as larger-than-life figures, prototypical in their stubborn postures of defiance and allegiance. In this community, elevation to the status of hero is ratified through the device of song, a commemorative poetry set to the evocative strains of the ballad melody. Thus, it is not surprising that with his dying breath, another corrido hero, Pedro el Chicharrón, ${ }^{2}$ calls for a ballad:

Decía Pedro el Chicharrón:

"Yo ya me voy de este mundo,

lo que les encargo muchachos, que me troven un corrido, pa que quede de recuerdo pa toditos mis amigos."

\author{
Pedro el Chicharrón spoke: \\ "I am now leaving this world, \\ what I ask of you, boys, \\ is that you write me a corrido, \\ so it can remain as a token \\ for every one of my friends."
}

The discussion that follows the performance of "Corrido de Sidonio," on the other hand, illustrates a markedly different form of discourse, one that is intended to inform rather than to commemorate. This stretch of talk consists of some 23 separate turns at speech as Ernesto, Raúl, Alejandro, and I explore a single esoteric detail referenced in the ballad-the metaphorical nickname of one of the protagonists. The discussion is initiated by Raúl, who is anxious to clarify for me the meaning of the term chichacola. We learn about the nasty character of the insect that has provided Teófilo with his nickname; remember, it is Teófilo's intransigence that opens the sequence of violent encounters. Raúl and Ernesto provide information concerning this creature's habitat (in the palms) and behavior (the bite is deadly for cattle). They even offer some possibilities for translating this label, causing Alejandro to chime in to clarify a possible misconception introduced in the suggested analogy to bees (unlike them, the chichacola doesn't fly). There is much redundancy in the descriptions, which derives from expressions of social solidarity as the interlocutors seek and receive confirmation from one another.

Other genres enter the picture as the discussion acquires a momentum of its own, increasingly centered on the verbal interplay between Ernesto and Raúl. Ernesto embarks on a personal-experience narrative (episode 18) meant to illustrate the pesky but less-than-fatal character of the insect. Then Raúl (epi- 
sode 19) pokes fun at Ernesto, insinuating that the insects have bitten him because they realize he is gathering coconuts that do not belong to him. Ernesto dodges this ploy, and the conversation about the chichacola winds down. It is evident that this segment of talk proceeds in an entirely different fashion from the discourse of the song itself. Instead of skipping lightly from one referent to another, this discussion remains firmly anchored in the description and depiction of the chichacola's features. Instead of confinement to the voice of an authoritative narrator, there is here a round-robin of voices, and the conspicuous display of mutual respect among them. Stylistically, we move from the demanding contours of sung poetry to the circumstantial tones of conversation and conversational narrative.

The exchanges between Ernesto and Raúl that are interspersed in the singing of the ballad are particularly interesting, showing how permeable is the boundary, and how tight the bond, between informative and commemorative discourse. Thrice between stanzas (after stanzas 4, 5, and 7), as the guitars carry the melody, and once between couplets within a stanza (stanza 7), Ernesto tosses out comments to Raúl (who responds in kind) concerning the plot of the story in progress. These interjections take the form of a private (though publicly witnessed) dialogue between Ernesto and Raúl, realized most fully in the first instance when Raúl responds, "Bastante” [plenty]. Ernesto's comments are either ironic or emphatic in character. In the first of them (after stanza 4), Ernesto states (ironically) that Filimón Lorenzo was very fond of Sidonio Mayo (the ballad has just noted that he wanted "to fill him with lead"). The second one (after stanza 5) introduces a note of dramatic irony as the narrator displays, again in an ironic vein, a wider grasp of the circumstances than was available to the story's protagonist. The third interjection (in the middle of stanza 7) clarifies the identity of a character in the plot, the unfortunate Prisca Soto, who dies in his wife's place. The final one (at the end of stanza 7) is emphatic in character, underscoring the significance of the notion of siño (from standard Spanish seño, "sign"), used here to mean "omen of death." 3

All of these interjections are delivered in a slightly stylized manner, suggesting that each is a complex proposition requiring careful decoding. They are prompted by Ernesto's awareness that Raúl stands in a position of special intimacy to the story told (imperfectly) in the ballad. Later, after the discussion of the chichacola, Raúl explained this connection, triggering the following exchange:

Raúl: Sidonio Mayo es primo hermano de mi papá.

[Sidonio Mayo is the cousin brother of my father.]

Ernesto: Allí lo va a platicar él.

[Now he's going to tell you about it.]

Raúl: Ah, es de Aprisco, acá del municipio de Copala, de Copala, ¿verdad? 
[Ah, he is from Aprisco, here in the town of Copala, from Copala, right?]

Ernesto: Sí, Copala.

Raúl: Ahá, entonces yo,

el pleito no sé como estaría, ¿no?

Lo que sí sé es que es familia de mi papá,

de los Mayos, de Machelia.

[Aha, so as for me,

I don't know what the problem was about, you see?

What I do know is that he is related to my father, one of the Mayos, Machelia's boy.]

John: Um.

Raúl: Entonces ahí donde empieza, pues, este,

empieza la pelea de familia contra familia, ¿no?

Así que si tu me matas un familial,

yo voy y me emparejo,

no mas que sea un familial, lo que sea, ¿verdad?

[So, there where it begins, well, you know,

the battle of family against family begins, right?

So if you kill one of my relatives,

I will go and get even with you,

as long as it is a relative, anybody, right?]

John: Peligroso.

[Dangerous.]

Ernesto: Sí, entonces, estos corridos son puros verídicos, verídicos, sí.

Así como fue el . . o sea los antecedentes,

son originales de acá de la costa,

de la Costa Chica de Guerrero.

[Yes, so these corridos are the pure truth, the truth, yes.

Just like it was . . let's say the antecedents, they are native to here, to the coast,

to the Costa Chica of Guerrero.]

Raúl defines his special location with respect to the ballad plot: the main character is primo hermano, a first cousin of his father; this fact confers on Raúl a quasi-celebrity status for the moment. Ernesto yields the floor, and Raúl brings to bear additional information concerning his father's primo hermano: his place of origin, the particular branch of the family (de Machelia, "of Machelia," presumably the name of one of Raúl's grandmothers). Raúl goes on to describe the atmosphere of vicious feuding that the story references, and Ernesto concludes with an assessment of the truth value of the songs and their connection to the Costa Chica.

The Ballad of Sidonio, then, emerges with a multifaceted communicative event featuring generically distinct uses of language. The singing of Sidonio's corrido, with its companion discussion and dialogue, illustrates prominently 
contrastive discourse styles, what I have called the commemorative and the informative. It is evident that these styles work together in conveying the story of Sidonio Mayo, and also in assessing its meaning and relevance. Let us turn now to a more rigorous discussion of the informative and commemorative speaking styles.

\section{Stylized Intonation}

I situate the discussion in a current trend in the study of language, one that embraces phonesthetic elements of language as central to any analysis of meaning. Structural and generative linguistics tended to set aside such phonological components as stress, intonation, pacing, and phrasing in a residual category of paralinguistics, hovering on the fringe of language but not properly linguistic (that is, contributing to language meaning in a systematic way). Some current linguistic research proposes a virtual inversion of this principle, capitalizing on the work of precursors such as M. A. K. Halliday, David Crystal, Fred Householder, Dwight Bolinger, and others. Those active in this movement view a number of paralinguistic features, notably stress and intonation, as legitimate and even essential ingredients in semantic description. The revision of linguistic science proposed here elevates what were previously considered merely "expressive" features, the inherent rhythms and melodies of speech, to a position of analytical importance. It is at this juncture that the orientations of linguists and folklorists coincide, for students of verbal art are drawn to these very same features of speech prosody.

A promising point of departure for the present discussion is the notion of stylized intonation, most familiar to us in the guise of what has often been referred to as the calling tone: ${ }^{4}$

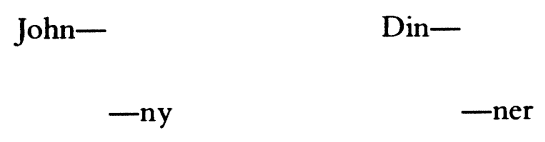

Ernesto's asides to Raúl in the performance of Sidonio's ballad illustrate the employment of stylized intonation in conversational practice. These commentaries make use of an exaggerated rise on stressed syllables that frames the utterance as one in need of special handling. Consider the first of them:

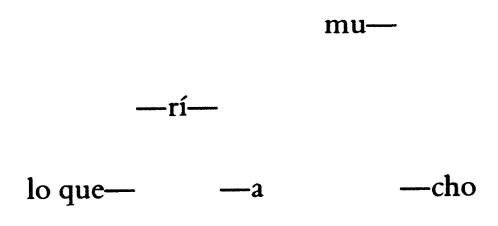

[He was really fond of him.]

The sequence of higher-than-expected rises marks this phrase acoustically; 
here, stylized intonation indicates the presence of irony and provides a clue that the semantic intent of the speaker is at odds with the literal content of the utterance.

Robert Fogelin argues that "the indirect content of an ironic utterance is determined by the corrective judgment that it naturally invokes within the context in which it is made" (1988:10, emphasis mine). Ernesto's ironic asides ("he was really fond of him" and "it was easy") are palpably out-of-phase with the drift of the narrative, triggering the "corrective judgment" of which Fogelin speaks. But the process is contrived rather than natural; Ernesto makes studied eye contact with Raúl as he speaks, shakes his head back and forth, and couches these utterances in a stylized intonation, all in an effort to assure the detection of his ironic intent. Irony of attitude has its counterpart in irony of accent, carried largely (at least in Spanish and, I believe, in English) through the introduction of stylized intonation.

Stylized intonation emerges as a prominent linguistic variable once we become attuned to its presence in a wide range of speaking styles. D. Robert Ladd, Jr., proposes a continuum of stylization effects running from the calling tone to more fully realized speech musicality:

Stylized variants are characterized by level pitches: stylized fall is a stepping-down sequence of two level pitches, and stylized rises . . . are a single level pitch. Various other acoustic qualitiesmore formalized melody and rhythm, and chanting tone of voice-are to be considered dimensions of gradience with the category "stylized." [1980:185]

Ladd elaborates a program for making stylized intonation a phonemic language component, based on a combination of all-or-nothing contrasts and gradient effects. This program envisions what Duncan Gardiner terms "a hierarchy of melodic form" from normal speech intonation to song (as cited in Ladd 1980:219).

Phonologically, the distinguishing feature of stylized intonation is the production of sustained pitches. Ladd remarks, citing a personal communication from Dwight Bolinger, that "the constant subtle ups and downs of pitchwhich are levelled in both music and stylized intonation-are the 'accompaniment of informative utterance' " (1980:219). In other words, speakers parse and focus their utterances, strategically allocating accentual and intonational resources to highlight significant bits of information in the flow of talk. As Ladd has it, "a speaker must take account of where he wants light and where he wants shadow" (1980:87). This orientation toward the conveyance of semantic particles results in an irregular prosody, characterized by imperfect rhythmic structures as speakers mark degrees of saliency. In such an enterprise there are relatively few opportunities to sustain a steady pitch, let alone to place such tones in any sort of periodic cycle. ${ }^{5}$

The discussion of stylized intonation points to the existence of another kind of utterance, one in which the conveyance of finite bits of information is not the principal objective. I propose that we label this contrastive discourse type 
commemorative utterance, and identify its primary phonesthetic characteristic as a movement toward regular prosodies, notably an isochronic spacing of stress and a melodic arrangement of sustained pitches. As we shall see, I offer the term commemorative in an etymological spirit, as a jointly sustained "calling to mind," a "mentioning together" (cum = together, memorare = to mention), rather than in its more specific modern usage as a tribute to a historical event or personage (see Skeat 1967). In this spirit, commemorative utterance need not reference the concrete past (though this is certainly a possibility, as in Sidonio's ballad); it may instead evoke a timeless charter rooted in an imagined past but encompassing the present and readily projected into the future. It need not be strictly narrative in character, although I suppose its references must necessarily index a supportive narrative design. But we will take up these content features presently.

Commemorative utterance evinces stylized intonation raised beyond levels associated with routine conversation. This stylization can take many forms, as George List showed long ago (1963). It can move toward chant, with the introduction of isochronic rhythm and the confinement of intonation to one or a few steady pitches. Or, it can exhibit complex alternations of steady pitches, featuring certain intervals in a specific sequence in the manner of song. Sidonio's ballad takes the latter route, chaining verbalization to a melody consisting of six musical phrases that define a harmonic journey from the minor tonic through the minor sub-dominant, with closure provided by the conventional $\mathrm{i}-\mathrm{V}-\mathrm{i}$ cadence.

We are dealing here with what Jan Mukarovsky identifies as "esthetically saturated speech" (1964). In such speech a somewhat autonomous aesthetic system takes over and organizes the flow of discourse. Rhythmic factors implicit in all speech are elevated to a position of prominence; accents are evenly spaced, and intonational contours are foregrounded by the tendency (sometimes elevated to the status of rule) to hit the same sustained pitches. Speech becomes a vehicle of sensuous patterning, as related or identical phonological elements recur in predictable sequence. These artistic uses of language can lead to a loss of semantic meaning, but they need not do so. When song lyrics do convey semantic meaning, we can inquire What is the impact of sensuous acoustic profiles-the melodies and their rhythms-on the explicit message of commemorative utterance?

Moreover, if stylized intonation is lexical in nature, as Mark Liberman (1978) and D. Robert Ladd (1980) assert, just what is its semantic burden? The answer to this question will lead us into the phenomenology of commemorative utterance and help us isolate the world of difference between Sidonio's ballad and the commentaries on it. Ladd proposes that stylized intonation conveys a sense of familiarity, of predictability; it announces that the content of the message is endemic to the situation and therefore lacking novelty (1980:173ff.). Here, Bolinger's observation that "poetry, music, and artistic utterance in general are designed to be repeated" takes on special importance. 
Bolinger continues: "Hearing a song or poem for the twentieth time can be a profoundly moving experience; hearing the daily news for even a second or third time is a crashing bore" (as cited in Ladd 1980:219). These comments point to a form and function nexus that merits further exploration. What is it about the leveling of pitches that creates this "repeatability"? And what exactly are the cultural uses of "repeatability"?

\section{The Power of Commemorative Speech}

We have isolated informative and commemorative utterance on two grounds: phonological (the movement to regular prosody) and functional (abandonment of informative intent). It appears that commemorative speech eschews the capacity to reference the mundane; its utterances are instead evocative of higher meanings and sacred truths, of the wellsprings of consensus within the speech community. Those "subtle ups and downs of pitch" associated with informative utterance characterize a usage that has the power to corral the furthest reaches of the ordinary, or, in the words of Maurice Bloch, "to communicate messages concerning particular events" (1974:62). On the other hand, commemorative discourse, in surrendering this empirical authority, gathers into itself the affective power to alter the mood of those who listen, to transport them to a transcendental plane of enhanced understanding.

Those who participate in song sessions where Sidonio's ballad and other corridos of this ilk are sung are transported beyond the realm of the ordinary to an archetypical realm of heroic gesture. The protagonists of these narratives shed their particularity and become emblematic of the collective ethos; their defiant stances are met with shouts of approval from the audience: $i$ así es Guerrero, puro gallo! [That's Guerrero, pure fighting cocks!] and i que viva la Costa Chica! [Long live the Costa Chica!]. A profound link is fashioned between story protagonists, song performers, and members of the audience who gather in a glow of shared identity. Sidonio and his companions sally forth as incarnations of the Costa Chica everyman, as quasi-mythical figures who portray in vivid detail the destiny that encloses and marks us all.

Removal to this heightened plane of significance lies behind the characterizations of the corrido repeatedly offered in Guerrero in, for example, Ernesto's assertions that these songs "are the pure truth" [son puros verídicos], or the statement commonly heard in Acapulco and along the Costa Chica that "as long as there are Guerrerenses [people from the state of Guerrero], there will be corridos." It can be demonstrated that the corridos of the Costa Chica are heir to all the disturbances of factuality that plague other kinds of narrative reports. But they are truthful, at last, in their evocation of a charged vision of reality, a vision that captures and celebrates the defining qualities of the idealized ballad community. The worldview of the ballads is mapped onto the general community; the demise of the ballads will coincide with the disappearance of this imagined community. 
It is instructive to view the handling of what Bronislaw Malinowski called "phatic communion" (1923) in the informative and commemorative portions of our field materials. In the conversational setting, the participants scrupulously nurture an evolving sense of communion, adopting a humble stance that affords scope to recurrent gestures of deference and mutual respect. Comparable gestures are frozen into the lyrics of the song (esúchenlo con esmero [listen to this with care]), but Sidonio's ballad seeks a less immediate demonstration of social solidarity that wraps the present moment in a timeless conceptual charter. The song projects a mythos that plumbs the very basis for collaboration within the community. By invoking the ultimate grounds of communal identity, commemorative discourse forces a movement from the immediate to the transcendent.

How do commemorative discourses such as Sidonio's ballad accomplish this shift of locus from the here and now to the eternal? We might seek a solution to this problem in the systematic correlation between the communicative factors that I have labeled formalization and efficacy (McDowell 1983). Formalization resides in the properties of the expressive code; efficacy is measured in the capacity of speech to "make things happen." Let's hypothesize that increasing levels of formalization contribute to higher degrees of performative efficacy. Naturally, this proposition is actualized in what Richard Bauman describes as "the culture-specific constellations of communicative means" (1977:22, emphasis deleted). What I have abstracted is a pattern of patterns; the initial ingredients are most certainly "rooted in culturally-defined scenes or events" (Bauman 1986:3), such as the ballad session in Cruz Grande.

When articulate verbalization continues within the medium of song, the phenomenological effects that I have linked broadly to commemorative discourse come into play. I believe that the possibility of special efficacy inheres in acoustically measured speech; naturally, social conventions regarding the content of such speech and the circumstances in which it is produced must conspire if this potential is to be realized. Often people endow their formalized speech production with what Roger Abrahams calls "the deepest and most complex multivocal and polyvalent signs and symbols of their repertoire of expression," forging a powerful convergence of sound and meaning, measured and allusive speech (1977:80). It is this variety of speech that can be guided toward the highest goals of individual and collective endeavor.

As previously noted, the utterances and speeches of commemorative discourse acquire a performative efficacy, the capacity to make and remake the world through speech (see Austin 1962; Searle 1969). Different levels of performative efficacy can be distinguished in the world's speech systems: phatic efficacy is associated with ceremonial speech forms celebrating the renewal of community (as demonstrated in the case of Sidonio's ballad); executive efficacy may be attributed to speech forms used in rites of passage rituals; and material efficacy is invoked in magico-religious uses of speech, which are sometimes thought capable of transforming physical reality. 
Mild stirrings of performative efficacy can be detected in ordinary conversation, when speakers make use of politeness formulas to soothe their interlocutors, or when proverbs or proverbial expressions are used to smooth over transitions from one topic or turn to another (McDowell 1985). But the full force of commemorative impact is felt in the more stylized speech registers, which make room for persistent and systematic formalization. In many societies it is the discourse of ritual specialists, shamans or native doctors, that exhibits the most intense convergence of formalization and efficacy. These specialists often produce a variety of speech that is so highly formalized as to be largely inaccessible to nonspecialists in the group. This speech of religious specialists is frequently accorded a supernatural potency (see Brown 1984; Malinowski 1923; McDowell 1989; Tambiah 1985; Weiner 1983).

\section{Speech Narcosis}

We are left with one final question: how does commemorative discourse actually implement these effects? For the moment, let's presuppose the existence of the necessary social instruments for channeling such effects, the local system of speech genres and events. If measured and allusive speech does indeed possess this transformative potential, and possess it across cultures, then its effects must originate in the phenomenology of speech reception, that is, in the somatic and cerebral dimensions of experiencing speech production. A cluster of related effects can be identified. For one thing, measured speech acquires an aura of autonomy, as if it existed beyond the confines of situated speech production. It is "fashioned for ease of detachment from situational context" (Bauman and Briggs 1990:74). The steady cadence of such speech argues for a level of necessity that eludes the perishable utterances of ordinary talk (see Opie and Opie 1959; Paredes 1964; Peek 1981). Phonologically patterned speech resists the forces of entropy and persists as something seemingly outside of the natural process, like a crystal or an elaborate spider web. It is not by chance that commemorative discourse in so many societies is thought to be the native dialect of the deities or the ancestors (see Fox 1988; Ong 1967; Peckham 1967).

Closely related to the experiential dimension of autonomy is that of transcendence, the perception of heightened significance, of a special meaning inhering in the syllables and words of speech production, typically a message that is available only to privileged insiders. At this juncture we can account for the prevalence of figurative reference, of metaphor and other tropes, of specialized vocabulary, in the world's commemorative discourses. The reluctance of Sidonio's ballad to tell its story is part of this same impulse, for this narrative opacity repels the uninitiated while gathering the initiated into a revisiting of fundamental cultural values. Commemorative discourse excels in the presentation of transcendental messages, messages that reference a recondite, privileged vision of reality. At the extreme, the verbal material of such discourse 
becomes detached from its semantic moorings and acquires an indexical function similar to that of ritual objects and paraphernalia (Murray 1977).

Underlying these impressions of autonomy and transcendence is a physiological effect I would label speech narcosis. As we have seen, the dramatic levels of speech efficacy associated with commemorative discourse originate in a confluence of two significant factors: on the acoustic plane, a movement toward regular speech prosodies; on the semantic plane, a movement toward the evocation of immanent truth. We are dealing here with a two-punch combination that first creates an affective receptivity by preparing the central nervous system of the recipient, and then drives home a transcendental revelation by invoking a privileged vision of ultimate reality. Speech narcosis, the moodaltering capacity of speech, derives from rhythmic enhancement in the acoustic medium working upon the central and peripheral nervous systems in complex ways that scientists are now beginning to understand.

Essentially, it appears that rhythmic acoustic stimuli are perfectly designed to interact with indigenous propensities and susceptibilities of the brain and lower orders of the human nervous system to produce what are sometimes referred to as "curious subjective effects" (Turner and Pöppel 1983). The impact of acoustically measured speech on the somatic and cognitive states of human beings can be diagnosed on several fronts. The palpable rhythms of commemorative discourse interact with the inherent rhythms of brain activity to produce the effect known as "driving," a reinforcement process that manages a significant transfer of energy to the brain through the introduction of an insistent external stimulus. Andrew Neher, one of the pioneers of this area of research, worked on the auditory driving produced by loud, fast drumming at approximately the frequency of alpha waves (8-13 cycles per second). Neher ascribes special potency to the acoustic profile of drumming:

A single beat of a drum contains many frequencies. Different sound frequencies are transmitted along different nerve pathways in the brain. Therefore, the sound of a drum should stimulate a larger area in the brain than a sound of a single frequency. A drum beat contains many low frequencies. The low frequency receptors of the ear are more resistant to damage than the delicate high frequency receptors and can withstand higher amplitudes of sound before pain is felt. Therefore, it should be possible to transmit more energy to the brain with a drum than with a stimulus of higher frequency. [1962:152]

Neher associates this transfer of energy with states of mental transport often described as trance or trance-like, ecstatic, visionary, or mystical (see also Bourgignon 1977; Prince 1968). He surmises that sensory driving causes a spillover effect, moving arousal from one region of the brain to adjacent regions.

Subsequent research has confirmed and extended these insights. It is now widely accepted that "repetitive auditory and visual stimuli can drive cortical rhythms and eventually produce an intensely pleasurable, ineffable experience" (d'Aquili 1983:262). Barbara Lex (1979) insists that these driving effects 
are registered at all levels of the human nervous system. She holds that sensory driving works upon the autonomous nervous system-the sympathetic and parasympathetic components-to simultaneously engage both the ergotropic (arousal) and the trophotropic (rest) mechanisms lodged there. Excitation of these systems combines with simultaneous activation of both brain hemispheres to create a "tuning," or sensitizing, of the central nervous system, and an overall organismic response that could be described as total engagement.

Frederick Turner and Ernst Pöppel describe the result of these effects as an enhanced utilization of the brain's potential in which "the linguistic capacities of the left brain . . . are forced into a conversation with the rhythmic and musical capacities of the right" (1983:302). They argue that "meter breaks the confinement of linguistic expression and appreciation within two small regions of the left temporal lobe and brings to bear the energies of the whole brain" (1983:306). Turner and Pöppel adduce several features of the human brain that figure in the affective power of measured speech. It is inherently rhythmic, and these rhythms can be "entrained" and "amplified"; it is hierarchical, a characteristic that could account for a coordination of somatic, affective, and conceptual effects; and it is self-rewarding, providing an important opening to "any external technique for calibrating and controlling" this capacity for self-reward, primarily through the release of endorphins (1983:282). Each of these attributes makes a contribution, but clearly the key here is the rhythmic character of the brain, for Turner and Pöppel maintain that "the master rhythm of human meter is not pulmonary but neural" (1983:298).

Finally, a link between acoustic pattern and transcendental meaning appears in the reaction of the brain in the presence of a rhythmic external stimulus. Lex notes that "driving techniques facilitate right-hemisphere dominance, resulting in gestalt, timeless, nonverbal experiences" (1979:146). D'Aquili suggests that this wholly engaged brain activates what he calls the holistic operator, lodged in the sensory strip of the right cortex, an operator that "permits the world or significant portions of the world to be viewed as a whole or as a gestalt" (1986:148). He locates "a sense of meaning or wholeness which transcends the constituent parts" along an "aesthetic-religious continuum" ranging from the literary pleasures to the experience of "cosmic consciousness" in religious rites (1986:158-159). At one pole of this continuum, d'Aquili discerns what he calls absolute unitary being, a mystical vision that erases awareness of boundaries and places the self in harmony with all creation.

Eugene d'Aquili notes that "rhythmic or repetitive behavior synchronizes the limbic discharges (i.e., the affective states) of a group of conspecifics," and this brings us back to the harnassing of speech narcosis in the embrace of socially defined institutions and settings (1983:263). Commemorative discourse, with its movement toward regular prosodies, plays upon the rhythmic susceptibility of the human nervous system to engender in the individual, or in a group of assembled individuals, an altered state of consciousness characterized by the wholly engaged brain and autonomic system components. These al- 
tered states of consciousness are productive of transcendental understanding when discourse is saturated with the proper cultural content. If these experiences take place in the context of occasions especially tailored to stimulate and exploit such states of mind, the various levels of performative efficacyphatic, executive, and material-are the result. Commemorative discourse mediates between the cultural foundations of the community and genetically specific vulnerability of the individual, thereby facilitating a host of transcendental experiences instrumental in the conduct and reproduction of society.

\section{Conclusion}

Folklorists have grappled only intermittently with the affective qualities of the materials we study (see Abrahams 1983; Armstrong 1981; Feld 1982; Glassie 1989). Although folklore is still widely recognized as "artistic communication in small groups" (Ben-Amos 1971), there have been surprisingly few formulations of the contribution of artifice in this communicative process. I argue in this article that folklore's affectivity derives from a convergence of three elements: the innate perceptual and conceptual equipment of our species; the formally patterned cultural artifact or utterance; and the appropriate social conventions. Looking back on the ballad session that included Sidonio's ballad, it is now clear that two different modes of consciousness are entailed in the distinction between the informative and commemorative portions of the exchange. The talk about la chicacola, that is, the talk given over to conversational exegesis of elements in the song, involves normal mental processing especially highlighting the language-oriented centers in the left brain. ${ }^{6}$ The performance of the song activates a different consciousness, stimulating levels of arousal that I have associated with the wholly engaged brain.

Specifically, the singing of Sidonio's song brings about a shared sense of identification with an archetypical model of community, embodied in the heroic worldview of the ballad. Such performances exhibit phatic efficacy; they build community by evoking the common ground of collective idealization. The staging of this consensual foundation in the musical strains of song acts as a conduit to a transcendental experience of this connectedness.

In this article I have been concerned with verbal expression only, but the progression from commemorative utterance to commemorative discourse, conceived as expressive productions in any medium composed of regular and periodic arrangements of the material substance of the host medium, suggests broader horizons for this mode of analysis. It is evident that other forms of traditional expressivity, for example the material and the kinetic, could be explored using this analytical scheme, although adjustments would have to be made to accommodate a different material substrate. Performances in any medium can gravitate toward higher levels of formal organization, which are always, as Gerard Manley Hopkins (see Hopkins 1959) and Roman Jakobson (1960) have alerted us, the product of the rhythmic alternation of like and un- 
like elements. These performances may also merge textural patterning with a transcendental mode of reference, and carry those in attendance to a higher plane of understanding.

In fact, the verbal elements I have selected for special emphasis here normally occur in conjunction with musical, kinetic, and material elements to compose multifaceted performance contexts. Commemorative discourse embraces the full range of human expression crafted to foreground high levels of formal organization and dedicated to the rehearsal of immanent truth.

John H. McDowell is Professor and Chair, Folklore Institute, Indiana University

\section{Notes}

An earlier version of this article was presented at the American Folklore Society Meeting in Saint John's, Newfoundland, October 1991. I would like to acknowledge Richard Bauman, Donald Braid, and Bruce Harrah-Conforth for their useful suggestions, and Miguel Arizmendi and Raúl Mayo for their assistance in the field. I would like to give special thanks to Carlos Fernandez for his help with the musical transcription of Sidonio's ballad. This research was supported in part by a grant from the National Endowment for the Humanities.

${ }^{1}$ Copies of the tape made that night, and other recordings made during that summer, are on deposit at the Archives of Traditional Music at Indiana University. All field materials referred to in this article were gathered on expeditions to the Costa Chica that I undertook in 1972, 1989, and 1990.

${ }^{2}$ Ballads about this character have been popular along the Costa Chica for many years. I recorded one in 1972 and another in 1989 and 1990; this text is taken from a recording that was made in 1989 in the same region. The hero is a strongman who was nicknamed el Chicharrón [the fried pork rind] because of his pockmarked face.

${ }^{3}$ This term does not appear in Santamaría 1959. It may in fact derive from the conjunction of seño and destino, producing the phonetic hybrid siño, meaning "omen of destiny."

${ }^{4}$ The following examples are rendered in conventional sociolinguistic form in which height on the printed page corresponds to relative pitch.

${ }^{5}$ Even so, informative utterance presents an acoustic profile that tends toward regularity at some moments, and certainly can be heard as partially regular by our pattern-oriented minds. Indeed, there is music in even the most ordinary of utterances.

${ }^{6}$ I am operating under the assumption that concepts of brain lateralization and hemispheric specialization are viable as long as one avoids simplistic notions of dominance and handedness (see Geschwind and Galaburda 1984).

\section{References Cited}

Abrahams, Roger. 1977. Toward an Enactment-Centered Theory of Folklore. In Frontiers of Folklore, ed. William Bascom, pp. 79-120. Boulder, Colo.: Westview.

Press.

1983. The Man of Words in the West Indies. Baltimore, Md.: Johns Hopkins University

Aguirre Beltrán, Gonzalo. 1958. Cuijla: Esbozo etnográfico de un pueblo negro. Mexico City: Fondo de Cultura Económico.

d'Aquili, Eugene. 1983. The Myth-Ritual Complex: A Biogenetic Structural Analysis. Zygon 18:247-269.

1986. Myth, Ritual, and the Archetypal Hypothesis. Zygon 21:141-160.

Armstrong, Robert Plant. 1981. The Powers of Presence: Consciousness, Myth, and Affecting Pres- 
ence. Philadelphia: University of Pennsylvania Press.

Austin, John. 1962. How to Do Things with Words. Cambridge, Mass.: Harvard University Press. Basgoz, Ilhan. 1986. Digression in Oral Narrative: A Case Study of Individual Remarks by Turkish Romance Tellers. Journal of American Folklore 99:5-23.

Bauman, Richard. 1977. Verbal Art as Performance. Rowley, Mass.: Newbury House. 1986. Story, Performance, and Event: Contextual Studies of Oral Narrative. Cambridge: Cambridge University Press.

Bauman, Richard, and Charles Briggs. 1990. Poetics and Performance as Critical Perspectives on Language and Social Life. Annual Review of Anthropology 19:59-88.

Ben-Amos, Dan. 1971. Toward a Definition of Folklore in Context. Journal of American Folklore 84:3-15.

Bloch, Maurice. 1974. Symbols, Song, Dance and Features of Articulation: Is Religion an Extreme Form of Traditional Authority? European Journal of Sociology 15:55-81.

Bourguignon, Erika. 1977. Altered States of Consciousness, Myths, and Rituals. In Drugs, Rituals, and Altered States of Consciousness, ed. Brian du Toit, pp. 7-23. Rotterdam: Balkema.

Brown, Michael. 1984. The Role of Words in Aguaruna Hunting Magic. American Ethnologist 11:545-558.

Feld, Stephen. 1982. Sound and Sentiment: Birds, Weeping, Poetics and Song in Kaluli Expression. Philadelphia: University of Pennsylvania Press.

Fogelin, Robert. 1988. Figuratively Speaking. New Haven, Conn.: Yale University Press.

Fox, James, ed. 1988. To Speak in Pairs: Essays on Ritual Languages of Eastern Indonesia. Cambridge: Cambridge University Press.

Geschwind, Norman, and Albert Galaburda, eds. 1984. Cerebral Dominance: The Biological Foundations. Cambridge, Mass.: Harvard University Press.

Glassie, Henry. 1989. The Spirit of Folk Art. New York: Abrams.

Goffman, Erving. 1981. Forms of Talk. Philadelphia: University of Pennsylvania Press.

Greenberg, James. 1989. Blood Ties: Life and Violence in Rural Mexico. Tucson: University of Arizona Press.

Gummere, Francis Barton. 1907. The Popular Ballad. Boston, Mass.: Houghton, Mifflin.

Hopkins, Gerard Manley. 1959. Journals and Papers, ed. Humphrey House. London: Oxford University Press.

Jakobson, Roman. 1960. Closing Statement: Linguistics and Poetics. In Style in Language, ed. Thomas Sebeok, pp. 350-377. Cambridge, Mass.: MIT Press.

Kermode, Frank. 1979. The Genesis of Secrecy: On the Interpretation of Narrative. Cambridge, Mass.: Harvard University Press.

Ladd, D. Robert, Jr. 1980. The Structure of Intonational Meaning: Evidence from English. Bloomington: Indiana University Press.

Lex, Barbara. 1979. The Neurobiology of Ritual Trance. In The Spectrum of Ritual: A Biogenetic Structural Analysis, ed. E. G. d'Aquili, C. D. Laughlin, Jr., and J. McManus, pp. 117-151. New York: Columbia University Press.

Liberman, Mark. 1978. The Intonational System of English. Ph.D. dissertation. Department of Linguistics, MIT.

List, George. 1963. The Boundaries of Speech and Song. Ethnomusicology 7:1-16.

Malinowski, Bronislaw. 1923. Argonauts of the Western Pacific. New York: Dutton.

McDowell, John. 1983. The Semiotic Constitution of Kamsá Ritual Language. Language in Society 12:23-46.

1985. The Poetic Rites of Conversation. Journal of Folklore Research 22:113-132.

1989. Sayings of the Ancestors: The Spiritual Life of the Sibundoy Indians. Lexington: University Press of Kentucky.

Mukarovsky, Jan. 1964. Standard Language and Poetic Language. In A Prague School Reader on Esthetics, Literary Structure, and Style, ed. Paul Garvin, pp. 17-30. Washington, D.C.: Georgetown University School of Languages and Linguistics. 
Murray, David. 1977. Ritual Communication: Some Considerations Regarding Meaning in Navajo Ceremonials. In Symbolic Anthropology: A Reader in the Study of Symbols and Meanings, ed. J. Dolgin, D. Kemnitzer, and D. Schneider, pp. 195-220. New York: Columbia University Press.

Neher, Andrew. 1962. A Physiological Explanation of Unusual Behavior in Ceremonies Involving Drums. Human Biology 34:151-160.

Ong, Walter. 1967. The Presence of the Word. New Haven, Conn.: Yale University Press.

Opie, Iona, and Peter Opie. 1959. The Lore and Language of Schoolchildren. Oxford: Clarendon Press.

Paredes, Américo. 1964. Some Aspects of Folk Poetry. Texas Studies in Literature and Language 6:213-225.

Peckham, Morse. 1967. Man's Rage for Chaos: Biology, Behavior, and the Arts. Philadelphia: Chilton Books.

Peek, Phillip. 1981. The Power of Words in African Verbal Arts. Journal of American Folklore 94:19-43.

Prince, Raymond, ed. 1968. Trance and Possession States. Proceedings, Second Annual Bucke Memorial Society. Montreal: Bucke Memorial Society.

Santamaría, Francisco. 1959. Diccionario de mejicanismos. Mexico City: Editorial Porrua.

Searle, John. 1969. Speech Acts: An Essay in the Philosophy of Language. Cambridge: Cambridge University Press.

Skeat, Walter. 1967[1882]. A Concise Etymological Dictionary of the English Language. Oxford: Clarendon Press.

Tambiah, Stanley. 1985. Culture, Thought, and Social Action. Cambridge, Mass.: Harvard University Press.

Turner, Frederick, and Ernst Pöppel. 1983. The Neural Lyre: Poetic Meter, the Brain, and Time. Poetry 142:277-309.

Weiner, Annette. 1983. From Words to Objects to Magic: Hard Words and the Boundaries of Social Interaction. Man 18:690-709.

Wilgus, D. K., and Eleanor Long. 1985. The Blues Ballad and the Genesis of Style in Traditional Narrative Song. In Narrative Folksong: New Directions. Essays in Appreciation of W. Edson Richmond, ed. Carol Edwards and Kathleen Manley, pp. 437-482. Boulder, Colo.: Westview. 